\title{
Comparison of microbial contamination at various sites along the Plankenburg- and Diep Rivers, Western Cape, South Africa
}

\author{
AN Paulse ${ }^{1}$, VA Jackson ${ }^{1}$ and W Khan ${ }^{2 *}$ \\ ${ }^{1}$ Department of Biomedical Sciences, Faculty of Health and Wellness Sciences, Cape Peninsula University of Technology, \\ Bellville 7535, South Africa \\ ${ }^{2}$ Department of Agricultural and Food Sciences, Faculty of Applied Science, Cape Peninsula University of Technology, \\ Cape Town 8000, South Africa
}

\begin{abstract}
This study was aimed at investigating and comparing the microbial contamination levels at various sites in the Plankenburg and Diep Rivers in the Western Cape, South Africa. Sampling of sites along the Plankenburg River started in June 2004 and continued for a period of 1 year until June 2005. Sampling of the Diep River sites started in March 2005 and continued for a period of 9 months until November 2005. Faecal coliform (FC) and E. coli (EC) counts were determined by means of the most probable number (MPN) technique, the number of culturable cells were determined using the heterotrophic plate count (HPC) technique and total microbial counts were evaluated by Flow cytometric analysis (FCM). The highest microbial counts for the Plankenburg River were observed at Site B where the highest MPN, FC, E. coli and total FCM counts of $9.2 \times 10^{6}$ (Week 14), $3.5 \times 10^{6}$ (Week 39) and $3.5 \times 10^{6}$ micro-organisms/100 $\mathrm{m} \ell$ (Week 39) and $2.1 \times 10^{8}$ micro-organisms/ $\mathrm{m} \ell$ (Weeks 1 and 39) respectively, were recorded. The highest HPC recorded for the Plankenburg River was $7.9 \times 10^{6}$ micro-organisms $/ 100 \mathrm{~m} \ell$ (Week 44, Site A). Site B is situated close to an informal settlement where waste effluents from stormwater drainage pipes enter the river system. In addition, other possible contamination sources included agricultural (Site A) and industrial (Site C) areas bordering the Plankenburg River. The highest total MPN, FC and E. coli counts in the Diep River were $5.4 \times 10^{6}$ (Week 23) and $1.6 \times 10^{6}$ micro-organisms $/ 100 \mathrm{~m} \ell$ (FC and E. coli, respectively (both in Week 23)), recorded at Site B. The highest HPC and total FCM counts of $1.7 \times 10^{7}$ micro-organisms/100 m $\ell$ (Week 14 ) and $2.5 \times 10^{9}$ micro-organisms $/ \mathrm{m} \ell$ (Week 23), respectively, were also recorded at Site B. This site was identified as the most contaminated site along the Diep River and served as an accumulation point for waste effluents from the residential and industrial areas, which included paint and machine manufacturers. Other sources situated along the Diep River included storage and maintenance facilities for steel containers, a wastewater treatment plant and an oil-refinery. Most of the bacterial counts obtained for the Plankenburg and Diep Rivers exceeded the accepted maximum limit for river water for most of the sampling period.
\end{abstract}

Keywords: river water, micro-organisms, most probable number, heterotrophic plate count, flow cytometry, industrial area, residential area, informal settlement

\section{Introduction}

South Africa's major water sources are stored in dams and water abstraction schemes, which allow for the adequate and effective functioning of industry (e.g. power generation, food production, etc.), agriculture and domestic uses. Drought spells and point- and non-point source pollution has however, threatened the water availability, one of the country's most fundamental and indispensable national resources (Thukela Water Project Report, 2004).

Microbial agents, associated with waterborne outbreaks, include the bacterial organisms Salmonella, Campylobacter and Escherichia coli (E. coli) amongst others (Gerba, 1996), as well as viruses, protozoa, helminths and fungi. These microorganisms may lead to significant health risks in humans, especially infants, the elderly and immunocompromised. In severe infections, waterborne diseases may result in chronic illness and even death (Theron and Cloete, 2002). Muller et

\footnotetext{
* To whom all correspondence should be addressed.

疋 +27 21460 3175; fax: +27 21460 3193;

e-mail: khanw@cput.ac.za

Received 20 October 2008; accepted in revised form 23 April 2009.
}

al. (2001) investigated the occurrence of E. coli O157:H7 in selected river water samples in South Africa. The 204 samples screened were selected from 15 different sites where water was used for direct and indirect human consumption and domestic use. Even though none of the tested samples contained $E$. coli O157:H7, certain strains did however exhibit enterohaemorrhagic $E$. coli virulence properties, such as Shiga toxin 1 and 2 and enterohaemolysin, which could cause chronic health problems if ingested. In 2006 a cholera outbreak led to 1298 deaths in Angola with tens of thousands of people infected. A survey showed that contaminated drinking water, poor sanitation and dense urban living were regarded as the main cause of the outbreak, which began in Luanda. Communities in this rapidly growing capital live in desecrated, garbage-filled slums with no reliable sources of clean water (Timberg, 2006). During November 2008, 6072 cases of cholera infections and 294 subsequent deaths were reported in nine provinces of Zimbabwe. In the South African province of Limpopo during the same time period, 187 cholera cases were treated and 3 deaths (1 South African and 2 Zimbabweans) were reported. Cholera cases have also been reported in Zambia and Mozambique where people travelled through the Beitbridge area in Zimbabwe (Department of Health, 2008). An inadequate supply of clean drinking water and poor levels of hygiene have been 
implicated as the reasons for these outbreaks. According to the World Health Organisation (WHO), 16141 suspected cholera infections, with 775 reported deaths, have been documented in Zimbabwe since December 2008, with a fatality rate estimated at $4.8 \%$. Serious challenges also exist with controlling the current state of the outbreak as 460 cholera cases and 9 deaths have been reported in South Africa, mostly in the areas bordering Zimbabwe (WHO, 2008).

The Plankenburg River is approximately $10 \mathrm{~km}$ long and services various activities in the residential, industrial and agricultural sectors. The river system runs through the town of Stellenbosch (Western Cape Province), which is well known for its many wine estates. Adjacent to the town is the informal housing scheme of Kayamandi, which comprises a population of more than 22000 people. As documented by the Department of Water Affairs and Forestry (DWAF) (2001), 20\% of Kayamandi's inhabitants live in brick houses with in-house water connections and flush toilets, while the remaining $80 \%$ occupy backyard shacks and informal dwellings. The river also serves as a source of irrigation to farmers in the agricultural areas both up- and downstream from the settlement. In addition, the river flows through Stellenbosch's industrial area, which includes amongst others a clothing factory, a well-known cheese factory, spray painting and mechanical workshops. Further downstream the river courses through an area of wineries and yoghurt and dairy producing plants (Barnes, 2003).

The Diep River catchment which is approximately $65 \mathrm{~km}$ in length is located in the South Western Cape Region and is bordered by industrial and residential areas. The estuary is about 900 ha in area and consists of the Milnerton Lagoon and the Rietvlei Nature Reserve and Boating Club (Lochner et al., 1994). The Diep River-Rietvlei system has silted up significantly over the past few years which has resulted in extensive erosion (Grindley and Dudley, 1988) and can therefore be regarded as a storage area for sediment-rich water during floods. The sedimentation rate is enhanced by vegetation in the vlei, especially where treated sewage water is being released. The river is bordered by various industrial establishments ranging from spray painting to chemical manufacturers as well as a wastewater treatment plant and an oil refinery, which could all have a significant impact on the water source and the surrounding environment.

The aim of this study was to investigate and compare the microbial contamination at various sites along the Plankenbrug and Diep Rivers in the Western Cape, South Africa. The level of faecal contamination in the river water samples was determined by the most probable number (MPN) technique, while the conventional plate count technique was used to determine heterotrophic counts (HPC). Flow cytometric analysis was used to obtain total cell counts (the culturable and non-culturable populations) in the collected water samples.

\section{Materials and methods}

\section{Sampling sites}

Three sampling sites were identified along the Plankenburg River (Stellenbosch) location: Site A (Agricultural Farming and Residential Areas); Site B (Informal Settlement of Kayamandi) and Site C (Substation in Industrial Area) (Fig. 1). Sampling of sites along the Plankenburg River started in June 2004 and continued for a period of 1 year until June 2005.

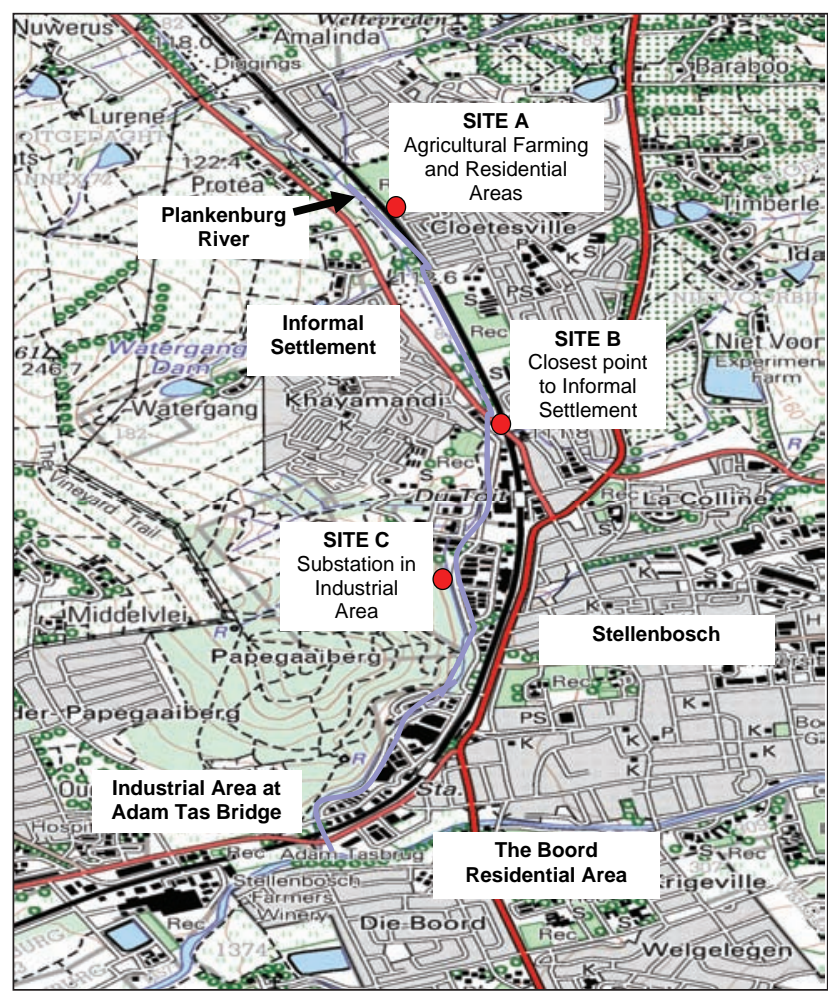

Figure 1

Map of the Plankenburg River indicating the different sampling points: Site $A$ - agricultural farming as well as residential areas; Site $B$ - close to an informal settlement and Site $C$ - Substation in the industrial area.

Sites for the Diep River (Milnerton) location: Site A (Zoarvlei Nature Reserve - Industrial as well as Residential Areas); Site B (Theo Marais Sportsclub - Industrial and Residential Area) and Site C (Potsdam Wastewater Treatment Works) (Fig. 2). Sampling of these sites started in March 2005 and continued for a period of 9 months until November 2005 (a new site had to be selected after the initial Site C dried up).

\section{Sampling for microbial contamination}

The temperature and $\mathrm{pH}$ of the river water (Table 1) at the sampling locations were measured using a hand-held mercury thermometer and portable $\mathrm{pH}$ meter (Hanna Instruments). For microbial analysis water samples were collected in $1 \ell$ sterile Nalgene-polypropylene bottles and stored on ice to maintain a low temperature.

\section{Most probable number (MPN)}

The MPN technique was modified by Barnes (2003) and involved the inoculation of sample water into lauryl tryptose tubes containing Durham tubes, followed by incubation for 48 hours at $37^{\circ} \mathrm{C}$ (indicating all gas-producing organisms). This differentiates between faecal coliforms ((FC) identifies all indicator organisms) and E. coli organisms within water samples (Oblinger and Koburger, 1975). Both these groups fall into the category of gas-producing micro-organisms (total MPN). All tubes indicating gas formation were regarded as a positive presumptive test and the presumptive coliform count was read off De Mans tables (American Public Health Association, 1992; 1995). The positive tubes were re-inoculated into brilliant green bile broth and tryptone water tubes respectively, accord- 


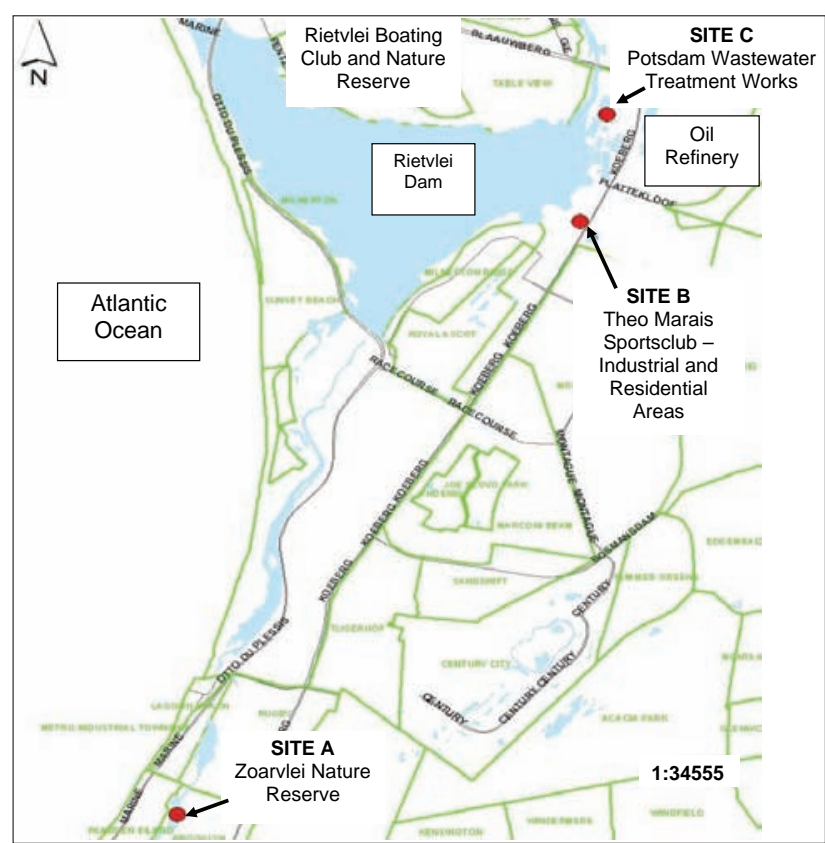

Figure 2

Map of the Diep River indicating the different sampling points: Site $A$ - Zoarvlei Nature Reserve (industrial as well as residential areas); Site $B$ - Theo Marais Sportsclub (Industrial and residential area); Site $C$ - Milnerton Waterworks (close to the oil refinery and residential areas of Milnerton)

ing to the guidelines set out by the South African Bureau of Standards (SABS, 1984). These guidelines also incorporate the standard methods set out by Standard Methods (1992; 1995). Positive tubes were incubated in a $44.5^{\circ} \mathrm{C}$ water-bath for $24 \mathrm{~h}\left(44.5^{\circ} \mathrm{C}\right.$ promotes growth of faecal coliforms (Massa et al., 1988)). Gas production in the brilliant green tubes (indicating faecal coliforms (FC)) was compared to growth in the tryptone water tubes (indicating $E$. coli). The presence of $E$. coli was confirmed with a colour change from clear to pink or red after the addition of Ehrlich's reagent into the tryptone water tubes.

\section{Heterotrophic plate counts (HPC)}

Total heterotrophic counts were done in triplicate on nutrient agar plates (NA) (Merck, Biolab Diagnostics) after serial dilutions $\left(10^{-1}\right.$ to $\left.10^{-7}\right)$ of water samples were performed. Plates were incubated for 3 to $4 \mathrm{~d}$ at $37^{\circ} \mathrm{C}$ (pathogens infecting humans grow at this optimum temperature). Thereafter, the number of visible cells (colony-forming units (CFU)) were counted and recorded.

\section{Flow cytometry (FCM)}

For the flow cytometry-based assay, individual samples were subjected to a Becton Dickinson FACSCalibur flow cytometer for analysis as outlined in Paulse et al. (2007). The Becton Dickinson FACSCalibur flow cytometer has a $15 \mathrm{~mW}, 488 \mathrm{~nm}$ argon-ion laser. A doublet discrimination module, which uses pulse width and area to eliminate cell clumping (doublets and triplets), in conjunction with a LIVE/DEAD ${ }^{\mathrm{TM}}$ bacterial stain, allows for the differentiation between bacterial cells and debris. Flow cytometry therefore, employs the principles of light scattering, light excitation and emission of fluorochrome molecules to generate data from particles or cells in the size range of $0.5 \mu \mathrm{m}$ to $40 \mu \mathrm{m}$ in diameter (Current Protocols in Cytometry, 2005). The addition of fluorescent beads enables the calculation of absolute or total cell counts in samples. The absolute number (cells $/ \mu \ell$ ) of positive cells in a sample can be determined by comparing cellular events to the bead events measured by the flow cytometer. For this study, the bacterial population was identified and gated on a forward scatter (FSC) vs. a side scatter (SSC) dotplot and a SSC vs. fluorescence channel 2 (FL-2) at 585/42 nm dotplot. The bead count was identified and gated on a SSC vs. fluorescence channel (FL-1) dotplot. All parameters were measured using a logarithmic amplification scale. A threshold of 52 FSC channels was set to remove sample debris. Only bacterial cells satisfying both gates were collected for subsequent analysis. Depending on the amount of debris present, certain samples were filtered through a $0.45 \mu \mathrm{m}$ filter before analysis. The staining procedure was performed by combining equal volumes of PI (propidium iodide) $(4 \mu \ell)$ and SYTO $9(4 \mu \ell)$ in BacLight ${ }^{\mathrm{TM}}$, dissolved in $1 \mathrm{~m} \ell$ sterile distilled $\mathrm{H}_{2} \mathrm{O}$. The stained samples ( $1 \mathrm{~m} \ell$ sample stained with $200 \mu \ell$ BacLight $^{\mathrm{TM}}$ ) were kept in the dark for 15 minutes, after which $50 \mu \ell$ liquid counting beads (BD ${ }^{\mathrm{TM}}$ Cell Viability Kit, BD ${ }^{\mathrm{TM}}$ Liquid Counting Beads) were added. The samples were then subjected to the flow cytometer for analysis and the concentrations of total cell populations were determined

(Eq. (1)). In order to avoid excessive compensation of fluorescence overlap, SYTO 9 green emittance fluorescence was measured in fluorescence channel 1 (FL-1) at 530/30 $\mathrm{nm}$ and the PI was measured in fluorescence channel 3 (FL-3) at 670/LP nm. As previously mentioned, the addition of beads allows for the calculation of total cell counts (i.e. viable plus dead cells) in samples. After optimisation, each water sample was subjected to the flow cytometer until a total of 250 counting bead events were detected. An E. coli laboratory strain was used as control or reference population to which unknown bacterial populations in planktonic samples could be compared during quantitative analyses (i.e. total cell count). 


\begin{tabular}{|c|c|c|c|c|c|c|}
\hline \multicolumn{7}{|c|}{\begin{tabular}{|l} 
TABLE 2 \\
Water temperature and pH of the Diep River from March 2005 to \\
Nov 2005
\end{tabular}} \\
\hline \multirow[t]{2}{*}{$\begin{array}{l}\text { Sampling } \\
\text { date }\end{array}$} & \multicolumn{2}{|c|}{$\begin{array}{c}\text { Before point } \\
\text { source of pollution }\end{array}$} & \multicolumn{2}{|c|}{$\begin{array}{c}\text { At point source of } \\
\text { pollution } \\
\text { (at Theo Marais) }\end{array}$} & \multicolumn{2}{|c|}{$\begin{array}{l}\text { After point source } \\
\text { of pollution } \\
\text { (at Potsdam } \\
\text { Wastewater } \\
\text { Treatment Works) }\end{array}$} \\
\hline & $\begin{array}{l}\text { Water } \\
\text { temp. } \\
\left({ }^{\circ} \mathrm{C}\right)\end{array}$ & $\mathrm{pH}$ & $\begin{array}{l}\text { Water } \\
\text { temp. } \\
\left({ }^{\circ} \mathrm{C}\right)\end{array}$ & $\mathrm{pH}$ & $\begin{array}{l}\text { Water } \\
\text { temp. } \\
\left({ }^{\circ} \mathrm{C}\right)\end{array}$ & $\mathrm{pH}$ \\
\hline Week 1 & 17 & 7.5 & 19 & 7.5 & 18 & 7.5 \\
\hline Week 5 & 13 & 7.3 & 16 & 7.7 & 18 & 7.7 \\
\hline Week 9 & 16.9 & 7.6 & 18 & 7.5 & 20 & 7.4 \\
\hline Week 14 & 12.3 & 7.3 & 15.5 & 8 & 17.4 & 7.8 \\
\hline Week 18 & 14.9 & 6 & 17 & 7.0 & 18 & 7.0 \\
\hline Week 23 & 14 & 6.5 & 17.8 & 7.0 & 17.9 & 7.0 \\
\hline Week 27 & 17 & 7 & 18.5 & 7.3 & 18.5 & 7.3 \\
\hline Week 32 & 19 & 7 & 18.8 & 7.5 & 22 & 7.3 \\
\hline Week 36 & 21 & 7.3 & 21.8 & 7.5 & 23.1 & 7.7 \\
\hline
\end{tabular}

and dead FCM counts are represented in Fig. 8.

The rivers investigated serve multi-purpose functions and it is important to note that the South African Bureau of Standards (SABS, 1984) (river water) and Department of Water Affairs and Forestry (DWAF, 1996a-c) (i.e. for domestic, recreational and agricultural purposes) have stipulated guidelines for faecal coliform counts to safeguard these natural water sources. The maximum acceptable levels of $E$. coli in natural water sources, such as rivers, have been stipulated in the SABS Guidelines (1984) and DWAF (1996a) as $>2000$ micro-organisms/100 $\mathrm{m} \ell$ and $>130$ micro-organisms $/ 100 \mathrm{~m} \ell$, respectively as counts above these levels may lead to waterborne infections. According to DWAF, where river water is used for recreational purposes, the FC counts should not exceed 2000 microorganisms/100 $\mathrm{m} \ell$ (DWAF, 1996a), while an E. coli count of $>130$ micro-organisms $/ 100 \mathrm{~m} \ell$, could lead to serious disease infections.

Most of the results for the MPN and FC

Bacterial populations are reflected in a specified gating area on a flow cytometric scattergram or dotplot.

Eq. 1: Number of events in cell region $\times$ Number of beads / test $\times$ dilution q. 1: Number of events in bead region $\times \frac{\text { test volume }}{\text { Nactor }}$

NOTE: (Bead concentration recorded at $988 / \mu \ell$ for BD Liquid Counting Beads and at 49827 beads per Trucount ${ }^{\mathrm{TM}}$ tube, both obtained from $\mathrm{BD}^{\mathrm{TM}}$ )

\section{Statistical analysis}

Repeated measures ANOVA (RMA) was performed on all data obtained as outlined in Dunn and Clark (1987), using Statisti$\mathrm{Ca}^{\mathrm{TM}}$. In each RMA, the residuals were analysed to determine whether they were normally distributed. In all hypothesis tests, a significant level of $5 \%$ was used as standards.

\section{Results and discussion}

Temperature and $\mathrm{pH}$ were monitored at all sites along the Plankenburg and Diep Rivers and are presented in Tables 1 and 2, respectively. However, the results for microbial parameters investigated fluctuated throughout the sampling period and no distinct correlation between water temperature, $\mathrm{pH}$ and differences in microbial numbers could be drawn. It should also be noted that the MPN, FC, E. coli and HPC counts were calculated per $100 \mathrm{~m} \ell$, while total, viable and dead FCM counts were calculated per $1 \mathrm{~m} \ell$.

\section{Plankenburg River}

\section{Most probable number (MPN), heterotrophic plate count (HPC) and flow cytometric analysis (FCM)}

The results obtained for MPN, FC, E. coli and HPC at Site A along the Plankenburg River are represented in Fig. 3, while the total FCM, as well as viable and dead FCM counts are represented in Fig. 4. The MPN, FC, E. coli and HPC results recorded at Site B are represented in Fig. 5 and the total FCM, viable and dead FCM are illustrated in Fig. 6. Results obtained for Site C along the Plankenburg River included total MPN, FC, E. coli and HPC counts represented in Fig. 7 and total, viable counts obtained from the Plankenburg River, on average exceeded the acceptable limit (SABS, 1984; DWAF, 1996a). During the sampling period at various sites along the Plankenburg River, no E. coli were detected. The highest total MPN counts observed at Site A along the Plankenburg River (Fig. 3) were $1.1 \times 10^{5}$ and $9.2 \times 10^{4}$ micro-organisms $/ 100 \mathrm{~m} \ell$ recorded in Weeks 23 and 44, respectively. The highest FC and E. coli counts recorded at this site were $5.4 \times 10^{3}$ (Week 18) and $9.2 \times$ $10^{3}$ micro-organisms $/ 100 \mathrm{~m} \ell$ (Week 44), respectively. Total culturable microbial counts (HPC) obtained at Site A are also depicted in Fig. 3 with the highest HPC recorded at $7.9 \times 10^{6}$ micro-organisms $/ 100 \mathrm{~m} \ell$ in Week 44 . The total FCM counts recorded at Site A ranged from $5.3 \times 10^{6}$ micro-organisms $/ \mathrm{m} \ell$ (Week 23) to $8.5 \times 10^{7}$ micro-organism $/ \mathrm{m} \ell$ (Week 5). A high FCM count was also observed in week 1 where $8.4 \times 10^{7}$ microorganisms $/ \mathrm{m} \ell$ were recorded.

Compared to the high HPC recorded at Site A in Week 44, a viable FCM count (Fig. 4) of $2.1 \times 10^{7}$ micro-organisms/ $\mathrm{m} \ell$ was observed. High viable FCM counts were also observed in Weeks 5, 32 and 48 where counts of $7.4 \times 10^{7}$, $2.5 \times 10^{7}$ and $2.3 \times 10^{7}$ micro-organisms $/ \mathrm{m} \ell$ were recorded. Corresponding HPC results recorded during Weeks 5, 32 and 48 were $4 \times 10^{5}, 1 \times 10^{7}$ and $3 \times 10^{4}$ micro-organisms $/ 100 \mathrm{m \ell}$. As previously mentioned, the HPC results were calculated per $100 \mathrm{~m} \ell$, while the viable FCM counts were calculated per $\mathrm{m} \ell$. The HPC were thus significantly $(\mathrm{p}<0.05)$ lower than the viable FCM count throughout the sampling period. The FCM technique distinguishes between ratios of live (viable), damaged (permeabilised) and dead (non-viable) cells, in conjunction with the LIVE/DEAD BacLight ${ }^{\mathrm{TM}}$ probe (Kell et al., 1998; Boulos et al., 1999). The results clearly show that micro-organisms that are generally undetected by conventional plate count techniques such as the HPC method can thus be detected by means of the FCM technique. In 2005, Pianetti et al. investigated the viability of Aeromonas hydrophila in various water samples by means of flow cytometry and compared the results to the conventional plate counting technique and spectrophotometric analysis. Results indicated that even though the optical density was low a greater A. hydrophila growth was observed with flow cytometric analysis while no plate count was obtained with the conventional plate count technique. 


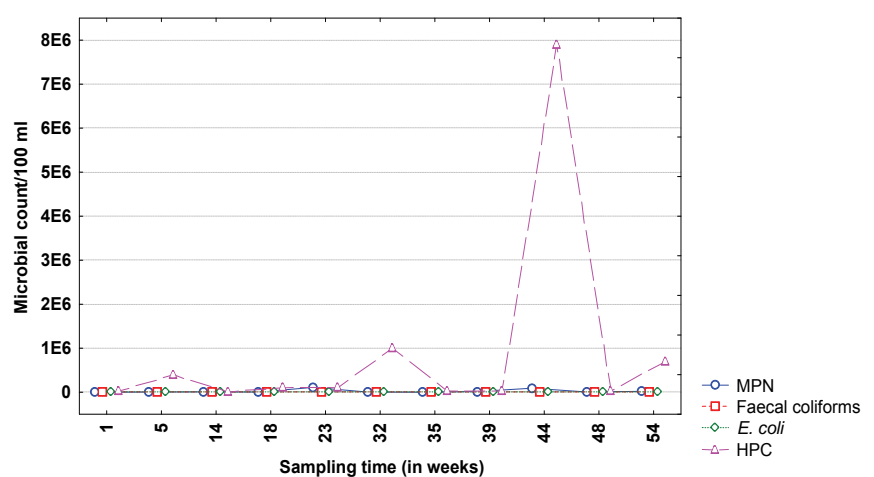

Figure 3

Comparison of most probable number [(MPN), representing all possible gas-producing organisms], faecal coliforms (FC), E. coli and heterotrophic plate counts (HPC) per $100 \mathrm{ml}$ of river water sample at Site A (Plankenburg River) over the sampling period.

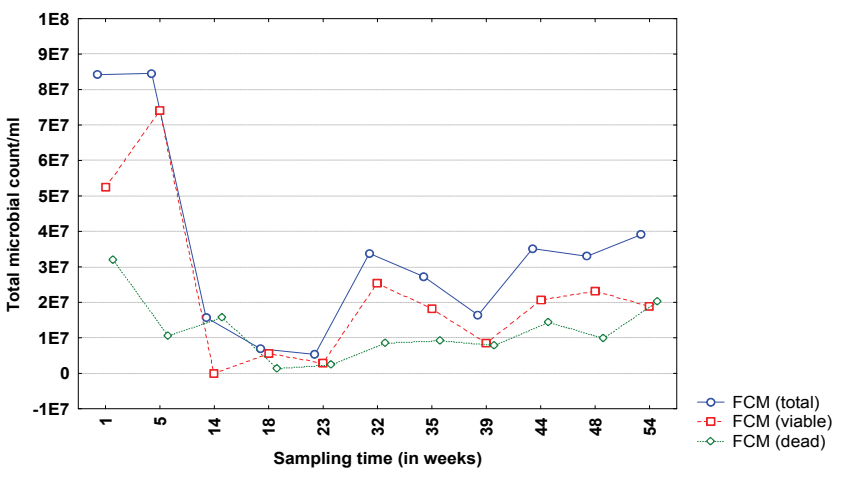

Figure 4

Enumeration of total, viable and dead bacterial cells within river water sample at Site A (Plankenburg River) by means of flow cytometric analysis over the sampling period.

By comparing the total MPN to the total FCM counts in the current study, results clearly show that the MPN, which represents the total gas-producing micro-organisms, did not have any significant influence on the total FCM count recorded at Site A. The peaks indicating the high total FCM counts in Fig. 4 do not correspond to the high MPN count observed in Weeks 1 and 5, respectively. The results clearly show that bacterial pollutants other than the possible gas-producing micro-organisms (total MPN) could be responsible for the increased total FCM count. As mentioned, Site A is bordered by agricultural farming and residential areas from which waste effluent flows into the river system, thereby contributing to possible contamination. Even though faecal contamination at this site does not contribute to increased health concerns, the faecal pollution observed at this site could be ascribed to the fact that this site serves as a cross-over point (humans and animals) between the residential area and one of the major roads leading into the town of Stellenbosch. A study conducted by Paulse and co-workers indicated that bacterial species such as Bacillus spp., Comamonas spp., Brevundimonas spp., and various members of the Enterobacteriaceae were present at this site (unpublished). Bacterial species such as Klebsiella oxytoca, Alcaligenes faecalis, Aeromonas sp., Lysobacter taiwanensis, Thermomonas fusca and Acinetobacter sp., indicator organisms of faecal contamination, were also identified at this site. Waste materials such as rubber and wooden products, glass and plastic, foam as well as paper, impede water flow at this site, allowing for possible microbial growth and biofilm formation.

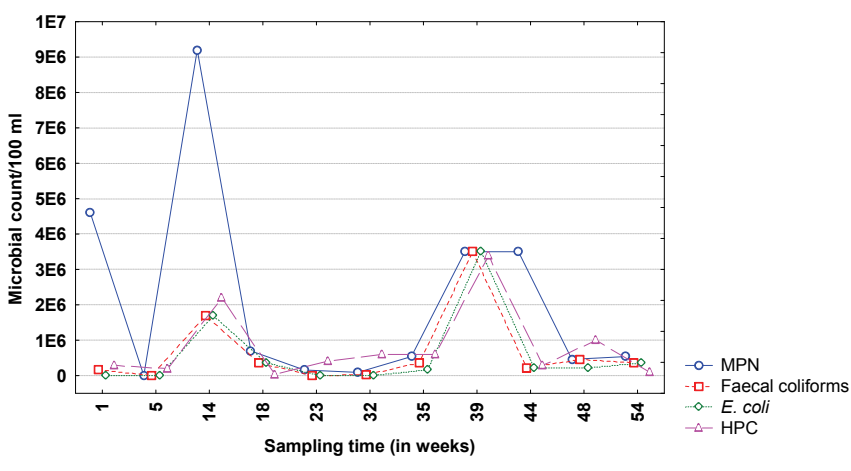

Figure 5

Comparison of most probable number [(MPN), representing all possible gas-producing organisms], faecal coliforms (FC), E. coli and heterotrophic plate counts (HPC) per $100 \mathrm{ml}$ of river water sample at Site B (Plankenburg River) over the sampling period.

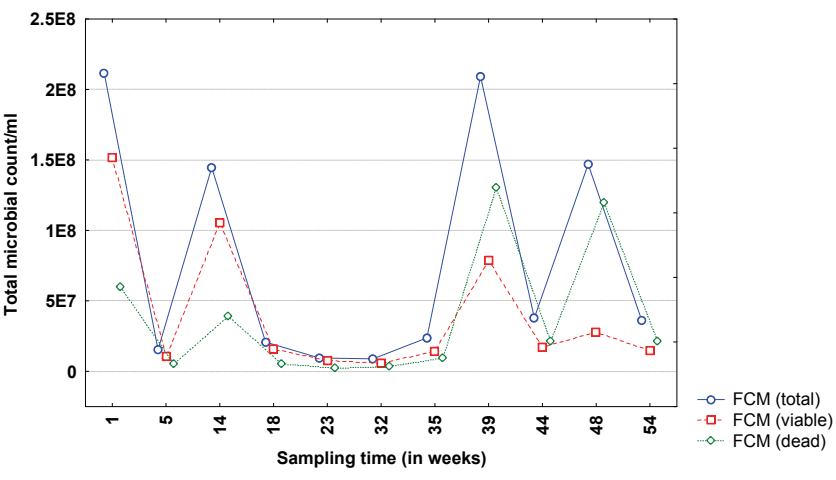

Figure 6

Enumeration of total, viable and dead bacterial cells within river water sample at Site B (Plankenburg River) by means of flow cytometric analysis over the sampling period.

In a previous study conducted by Paulse et al. (2007), increased microbial counts were obtained from materials to which biofilm communities were attached (results not shown). Research has also shown that pathogens survive longer in water and soil where organic matter, which provides attachment substrates and nutrients to micro-organisms, is readily available (Perri and Fallon, 1998; Fischer et al., 2003).

Compared to the MPN, FC and E. coli counts obtained at Site A, a considerably higher influx of faecal contaminants could be observed at Site B (Fig. 5) along the Plankenburg River. The highest MPN counts recorded at this site were $4.6 \mathrm{x}$ $10^{6}$ (Week 1), $9.2 \times 10^{6}$ (Week 14), $3.5 \times 10^{6}$ (week 39) and $3.5 \times$ $10^{6}$ micro-organisms/100 $\mathrm{m} \ell$ (Week 44). In addition, the highest FC and $E$. coli counts were $1.7 \times 10^{6}$ (Week 14) and $3.5 \times 10^{6}$ (Week 39) micro-organisms $/ 100 \mathrm{~m} \ell$, respectively. The highest HPC results were also recorded in weeks 14 and 39 where counts of $2.2 \times 10^{6}$ and $3.4 \times 10^{6}$ micro-organisms $/ 100 \mathrm{~m} \ell$ were observed. The total FCM counts (Fig. 6) at this site were also higher for most of the sampling period with exceptions in Weeks 5, 32, 35 and 54. High FCM counts of $2.1 \times 10^{8}$ (Weeks 1 and 39) and $1.5 \times 10^{8}$ (Weeks 14 and 48) micro-organisms $/ \mathrm{ml}$ were observed at this site. Results clearly show that increased activity from total gas-producing micro-organisms (total MPN) had a significant $(\mathrm{p}<0.05)$ effect on the total FCM count recorded during the sampling period at Site $B$ as shown in weeks 1, 14 and 39 (not week 48 where a decreased total MPN was observed). The temperature and $\mathrm{pH}$ recorded at this site in Weeks 1,14 and 39 were $15^{\circ} \mathrm{C}(\mathrm{pH}=7.0), 11^{\circ} \mathrm{C}(\mathrm{pH}=7.1)$ and 


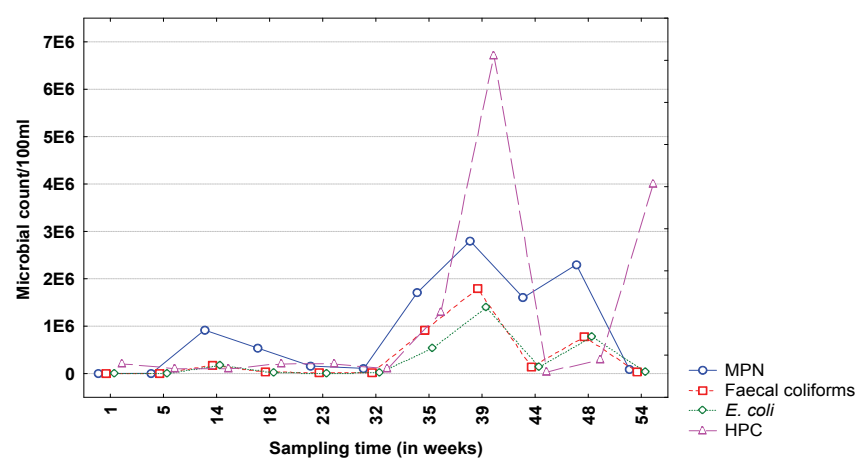

Figure 7

Comparison of most probable number [(MPN), representing all possible gas-producing organisms], faecal coliforms (FC), E. coli and heterotrophic plate counts (HPC) per $100 \mathrm{ml}$ of river water sample at Site C (Plankenburg River) over the sampling period.

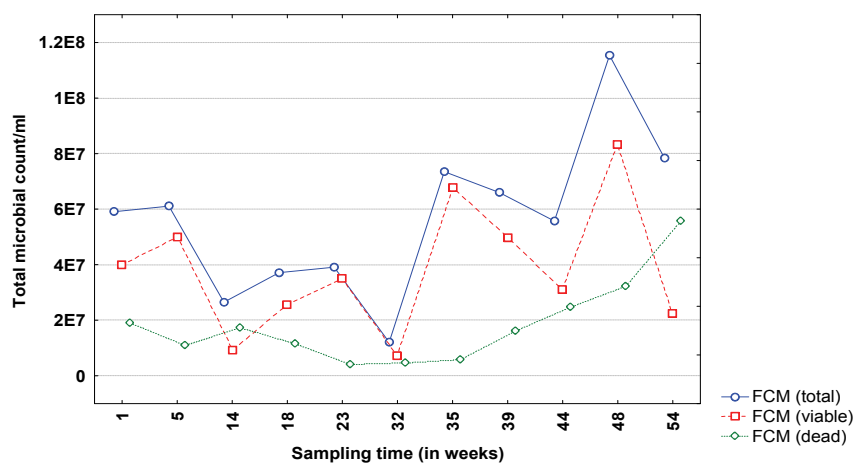

Figure 8

Enumeration of total, viable and dead bacterial cells within river water sample at Site C (Plankenburg River) by means of flow cytometric analysis over the sampling period.

$25^{\circ} \mathrm{C}(\mathrm{pH}=6.5)$, respectively (Table 1$)$. Even though an amplified microbial activity was recorded in Week 39, where the highest water temperature of $25^{\circ} \mathrm{C}$ was measured, the microbial counts fluctuated with changes in water temperature and $\mathrm{pH}$ values throughout the sampling period.

High viable FCM counts (Fig. 6) of $1.1 \times 10^{8}$ and $7.9 \times 10^{7}$ micro-organisms $/ \mathrm{m} \ell$ were obtained with flow cytometric analysis and the HPC results obtained for the same samples were considerably lower (2.2 x $10^{4}$ and $3.4 \times 10^{4}$ micro-organisms/ $\mathrm{m} \ell$, respectively).

It is evident from the results obtained that most of the general microbial activity was observed at Site B where the highest MPN, FC, E. coli and FCM counts were recorded. This site is situated in close proximity to the informal settlement of Kayamandi where the sanitation systems are inadequate to satisfy the needs of the inhabitants. The surrounding environment, stormwater drainage systems and waste containers are used as a means of disposal of faecal matter. The high MPN, FC and E. coli counts could thus be indicative of the possible impact of increased faecal activity on a river system (DWAF, 2001). It has also been noted during the study period that faecal waste from surrounding public sanitary facilities is flushed into the river at this site, increasing faecal matter and thus possible faecal coliform growth.

A study conducted by Paulse et al. (2007) also revealed MPN, FC and E. coli counts exceeding the maximum allowable limit for gas-producing micro-organisms in the Berg River, Western Cape. The highest MPN and FC counts of $3.5 \times 10$ micro-organisms $/ 100 \mathrm{~m} \ell$ respectively were observed at the site situated close to the informal settlement of Mbekweni. These high counts were ascribed to the possible influx of human and household waste from the informal settlement into the river system. In the study conducted by Paulse et al. (2009), bacterial species introduced into the river at Site B (Plankenburg River) included various members of the Enterobacteriaceae group such as Serratia sp., Citrobacter sp., Yersinia ruckeri and Enterobacter sp. thereby confirming faecal contamination at this site. The genus, Yersinia is considered one of the major human pathogens and may be the causative agent of plague in susceptible individuals, thereby raising health concerns in this area. Site B is also surrounded by dense vegetation which slows the water flow contributing to an increase in possible faecal contaminants (Fischer et al., 2003). The increased E. coli counts at this site thus raise alarming concerns as the community inhabiting these riverbanks is exposed to possible pathogens on a daily basis. In addition, various waste materials such as glass, plastic containers, rubber (vehicle tyres), steel (shopping carts) and electrical wiring, apart from organic waste material from surrounding plants and trees contaminate the river at this site. These and other materials such as sediment found within a river system may provide increased attachment surfaces for the colonisation of bacteria (Armon et al., 1997; Fischer et al., 2003).

The highest MPN counts recorded during the sampling period at Site C (Fig. 7) were $1.7 \times 10^{6}$ (week 35), $2.8 \times 10^{6}$ (week 39) and $2.3 \times 10^{6}$ micro-organisms $/ 100 \mathrm{~m} \ell$ (week 48). The corresponding FC counts were $9.2 \times 10^{5}, 1.8 \times 10^{6}$ and $7.8 \times$ $10^{5}$ micro-organisms $/ 100 \mathrm{~m} \ell$ during the same sampling weeks. Similarly, high E. coli counts were also recorded in the same weeks with the highest count of $1.4 \times 10^{6}$ micro-organisms/ $100 \mathrm{~m} \ell$, recorded in week 39 . High HPC results $\left(6.7 \times 10^{6}\right.$ micro-organisms $/ 100 \mathrm{~m} \ell$ ) were also observed during this week at Site C. During the present study, various materials sources observed at Sites A and B, were also observed at Site C. As mentioned, these materials provide ideal attachment surfaces to which micro-organisms adhere to and multiply in order to form biofilms (Armon et al., 1997).

The total FCM counts recorded at Site C (Fig. 8) ranged from $1.2 \times 10^{7}$ (Week 32) to $1.2 \times 10^{8}$ micro-organisms $/ \mathrm{m} \ell$ (Week 48). Site C is situated directly after the informal settlement of Kayamandi and close to a substation in an industrial area. The dense vegetation on the riverbanks at this site could possibly also contribute to slower water flow, thereby promoting microbial growth and increased numbers (Fischer et al., 2003). Compared to HPC analysis, the viable cells obtained by FCM analysis, were significantly higher $(p<0.05)$ than counts obtained by the heterotrophic plate count technique (Fig. 7). The highest viable FCM counts were observed in weeks 35 and 48 where counts of $6.8 \times 10^{7}$ and $8.3 \times 10^{7}$ micro-organisms $/ \mathrm{m} \ell$, respectively, were recorded. Corresponding HPC's recorded during Weeks 35 and 48 were $1.3 \times 10^{4}$ and $3.0 \times 10^{3}$ microorganisms $/ \mathrm{m} \ell$, respectively, once again indicating the reliability of the FCM technique. Monis et al. (2003) conducted a study on untreated and potable water samples in South Australia. Waterborne bacteria were enumerated by means of viable assays and flow cytometric analysis and the microbial numbers obtained, were compared to culture-based techniques. Counts obtained by the FCM technique yielded $5.56 \times 10^{2}$ and $3.94 \times 10^{4}$ active bacteria/m $\ell$ compared to the culture based techniques, which were two to four log cycles less. The results thus suggested that flow cytometry be used to detect physiologically active bacteria from the various water sources. 
In addition, downstream from this site the river services an agricultural area which greatly contributes to the international wine industry and thus the economy of the country. According to DWAF, river water used for irrigation, such as the Plankenburg River, should not exceed 1000 micro-organisms/100m $\ell$ (E. coli) in the water source. Increased counts as high as those observed at Site C, therefore could not only cause serious disease in humans (DWAF, 1996c), but also have major effects on the economy of the country.

Comparison of microbial counts recorded in the water samples obtained from the sites along the Plankenburg River indicate that Site B was the most contaminated point. The results show that the lack of proper sanitary facilities and poor service delivery in the informal settlement located at Site B could have contributed to the contamination of the river. Results clearly show that contamination at Site B could have been influenced by human waste from public toilet systems situated on the river banks which are flushed into stormwater drainage pipes which leads directly into the river at this site. The high microbial counts could lead to major health concerns as results for the MPN, FC, E. coli, HPC and FCM counts at all the sites investigated along the Plankenburg River exceeded the stipulated maximum limit for a water source used for recreational and irrigational purposes (DWAF, 1996a-c). Unless adequate waste removal and sanitary facilities are incorporated, maintained and monitored, continued contamination of the river will not only lead to increased and major health concerns within these communities but will also have a negative impact on the environment.

\section{Diep River}

\section{Most probable number (MPN), heterotrophic plate count (HPC) and flow cytometric analysis (FCM)}

In the Diep River, the results obtained for MPN, FC, E. coli and HPC at Site A are presented in Fig. 9, while the total, viable and dead FCM counts are represented in Fig. 10. The results recorded at Site B are represented in Fig. 11 and the total FCM, viable and dead FCM cells are illustrated in Fig. 12. Counts obtained from Site C included total MPN, FC, E. coli and HPC represented in Fig. 13 and total, viable and dead FCM counts in Fig. 14. The total MPN counts for the Diep River samples (Fig. 9) recorded at Site A ranged from $6.8 \times 10^{3}$ microorganisms/100 m $\ell$ (Week 9) to $3.5 \times 10^{5}$ micro-organisms/ $100 \mathrm{~m} \ell$ (Week 14). A high MPN count was also observed in Week 32 where counts of $1.7 \times 10^{5}$ micro-organisms $/ 100 \mathrm{m \ell}$ were recorded. The highest FC and E. coli counts recorded at this site were $1.1 \times 10^{4}$ micro-organisms $/ 100 \mathrm{~m} \ell$, respectively, both recorded in Week 5. The highest HPC counts of $1.7 \times 10^{6}$ micro-organisms $/ 100 \mathrm{~m} \ell$ and $2.1 \times 10^{6}$ micro-organisms $/ 100 \mathrm{~m} \ell$ were recorded in Weeks 1 and 23, respectively. The highest total FCM counts (Fig. 10) were recorded in Weeks 14, 23 and 32 where counts of $2.6 \times 10^{8}, 2.5 \times 10^{8}$ and $1.3 \times 10^{8}$ microorganisms $/ \mathrm{m} \ell$, respectively, were observed. Significantly higher $(\mathrm{p}<0.05)$ counts were obtained for the viable FCM count in comparison to the HPC technique. The highest HPC of $2.1 \times 10^{4}$ micro-organisms $/ \mathrm{m} \ell$ was recorded in Week 23 with a corresponding viable FCM count of $2.4 \times 10^{8}$ microorganisms $/ \mathrm{m} \ell$ observed during the same sampling period. High viable FCM counts were also observed in Weeks 14 and 32 where counts of $2.5 \times 10^{8}$ and $1.2 \times 10^{8}$ micro-organisms $/ \mathrm{m} \ell$ were recorded. This site along the Diep River borders residential and industrial areas and a natural wetland system is also

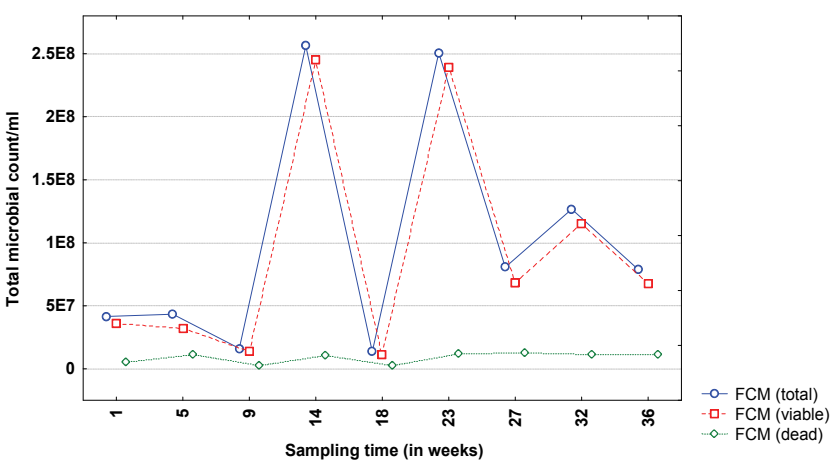

Figure 9

Comparison of most probable number [(MPN), representing all possible gas-producing organisms], faecal coliforms (FC), E. coli and heterotrophic plate counts (HPC) per $100 \mathrm{ml}$ of river water sample at Site A (Diep River) over the sampling period.

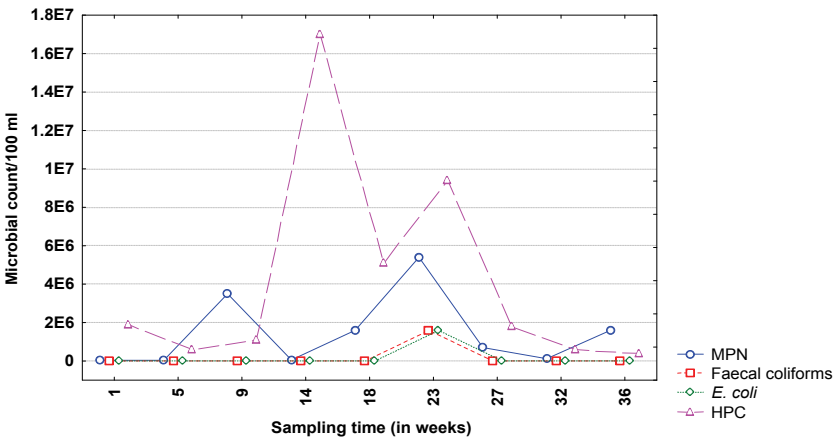

Figure 10

Enumeration of total, viable and dead bacterial cells within river water sample at Site A (Diep River) by means of flow cytometric analysis over the sampling period.

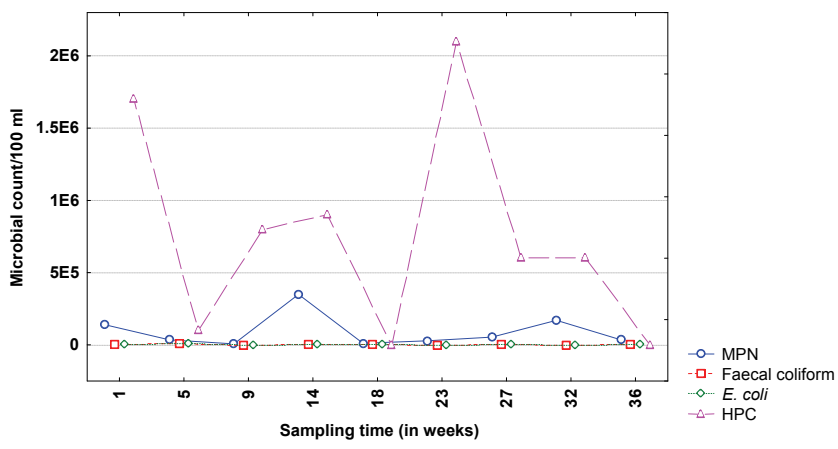

Figure 11

Comparison of most probable number [(MPN), representing all possible gas-producing organisms], faecal coliforms (FC), E. coli and heterotrophic plate counts (HPC) per $100 \mathrm{ml}$ of river water sample at Site B (Diep River) over the sampling period.

situated at Site A (Friends of Rietvlei Group, 2006-2008). Site A is situated before the wetland system, while Site B is located after the wetland system. Industries in the area include a steel container storage depot as well as various machine and tool manufacturers.

The highest MPN count recorded in the river at Site B (Fig. 11) (Theo Marais Sportsclub) was $5.4 \times 10^{6}$ microorganisms $/ 100 \mathrm{~m} \ell$ with corresponding FC and E. coli counts of $1.6 \times 10^{6}$ micro-organisms $/ 100 \mathrm{~m} \ell$, respectively, observed in Week 23. A higher HPC range was also observed at this site with the lowest count of $4 \times 10^{5}$ micro-organisms/ 


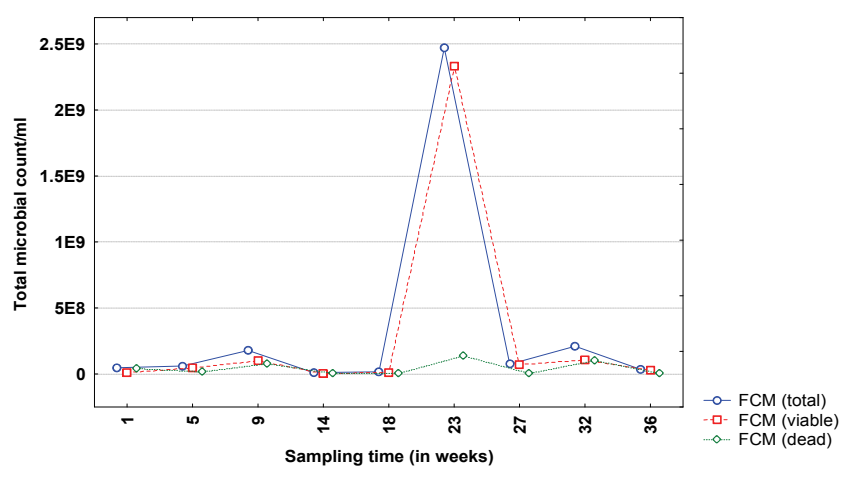

Figure 12

Enumeration of total, viable and dead bacterial cells within river water sample at Site B (Diep River) by means of flow cytometric analysis over the sampling period.

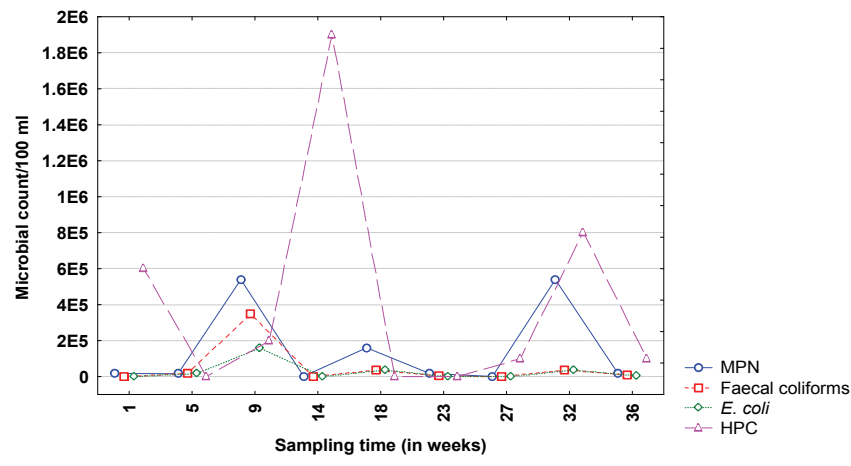

Figure 13

Comparison of most probable number [(MPN), representing all possible gas-producing organisms], faecal coliforms (FC), E. coli and heterotrophic plate counts (HPC) per $100 \mathrm{ml}$ of river water sample at Site C (Diep River) over the sampling period.

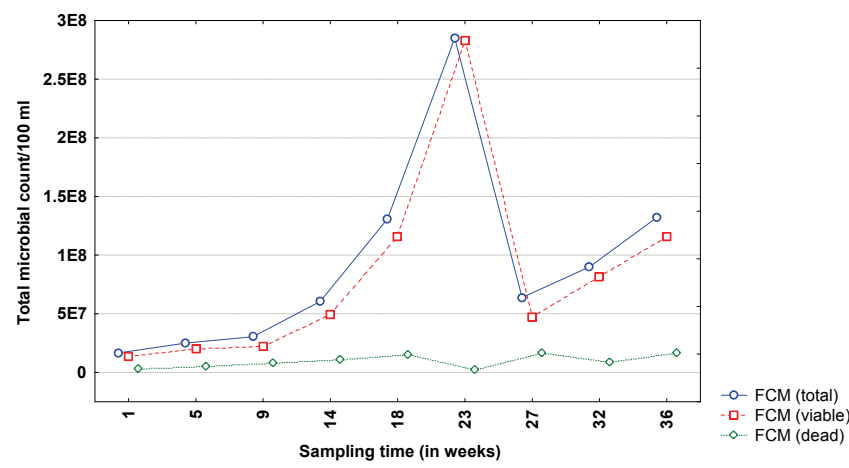

Figure 14

Enumeration of total, viable and dead bacterial cells within river water sample at Site C (Diep River) by means of flow cytometric analysis over the sampling period.

$100 \mathrm{~m} \ell$. The highest HPC results recorded were $1.7 \times 10^{7}$ micro-organisms $/ 100 \mathrm{m \ell}$ (Week 14) and $9.4 \times 10^{6}$ microorganism/100 $\mathrm{m} \ell$ (Week 23). In comparison to the highest total FCM counts (Fig. 12) recorded at Site A (Weeks 14, 23 and 32), higher counts were also recorded during Weeks 23 and 32 ( $2.5 \times 10^{9}$ and $2.1 \times 10^{8}$ micro-organisms $/ \mathrm{m} \ell$, respectively). Comparison of the viable FCM to the HPC results, showed that significantly higher $(\mathrm{p}<0.05)$ counts were obtained with the FCM technique as observed in Weeks 23, 32 and 36 where viable FCM counts of $2.3 \times 10^{9}, 1.1 \times 10^{8}$ and $3 \times 10^{7}$ microorganisms $/ \mathrm{m} \ell$, respectively, were recorded. Correspondingly,
HPC results were $9 \times 10^{6}, 6 \times 10^{5}$ and $4 \times 10^{6}$ micro-organism/ $\mathrm{m} \ell$, respectively, during the same sampling weeks. This corresponds to the results obtained in a previous study where significantly higher $(\mathrm{p}<0.05)$ viable FCM counts compared to the HPC results were recorded in the Berg River (Paulse et al., 2007). In the study by Paulse et al. (2007) the highest HPC count of $1.04 \times 10^{6}$ micro-organisms $/ \mathrm{m} \ell$ was recorded in Week 37 (Site B2) with a corresponding viable FCM count of $1.72 \times 10^{7}$ micro-organisms $/ \mathrm{m} \ell$ recorded for the same sampling time. At Site B2 high viable FCM counts were also recorded in Weeks 1 and 41, where counts of $1.4 \times 10^{7}$ and $1.9 \times 10^{7}$ microorganisms $/ \mathrm{m} \ell$, respectively were observed. The HPC results recorded during the same sampling period were $3 \times 10^{4}$ (Week 1) and $3 \times 10^{3}$ (Week 41) micro-organisms $/ \mathrm{m} \ell$. It was thus concluded that the FCM technique yielded a higher microbial count and is therefore a more reliable enumeration technique.

Compared to Site A the results recorded at Site B displayed evidence of significantly high gas-producing microbial growth and activity. This site is situated in an industrial area with industries ranging from spray painting, paint and chemical manufacturers to car wash facilities and pharmaceutical companies. A residential area is also situated in close proximity to Site B. In addition, the site is also in an open area with minimum foliage for shade and where increased temperature could thus lead to higher water temperatures and thus increased microbial activity. Microbial results fluctuated at Site B and no correlation could be drawn between the overall high counts experience in Week 23 and the water temperature and $\mathrm{pH}$ (Table 2) recorded during the same sampling period.

Site C is situated at the Potsdam Wastewater Treatment Works. Results obtained at this site along the Diep River are represented in Figs. 13 and 14. The highest MPN, FC and E. coli counts (Fig. 13) recorded at this site were $5.4 \times 10^{5}$ (Weeks 9 and 32), $3.5 \times 10^{5}$ (Week 9) and $1.6 \times 10^{5}$ microorganisms/100 $\mathrm{m} \ell$ (Week 9), respectively. Compared to Site B, increased FC and E. coli counts (for most of the sampling period), were observed at Site $C$ which could indicate increased faecal contamination in this area. The Potsdam Water Treatment Works receives wastewater directly from the surrounding residential areas as well as an oil refinery. The highest HPCs recorded at Site C were $1.9 \times 10^{6}$ micro-organisms $/ 100 \mathrm{m \ell}$ in week 14. The highest total FCM counts were observed in Weeks 18, 23 and 36 where counts of $1.3 \times 10^{8}, 2.8 \times 10^{8}$ and $1.3 \times 10^{8}$ micro-organisms $/ \mathrm{m} \ell$ were recorded.

Overall an initial increase in the HPC results from Site A to Site B was followed by a decrease in the total HPC recorded at Site C (with exception of Week 32). Even though Site C is an enclosed facility and the possibility of river water being used for domestic use is low, the microbial counts observed at this site may still raise major health concerns as the Diep River runs into the Rietvlei Nature Reserve, which is used for recreational purposes. As mentioned DWAF stipulates that where river water is used as a means of recreation, a faecal coliform and $E$. coli count of $>2000$ micro-organisms $/ 100 \mathrm{~m} \ell$ and $>130$ micro-organisms $/ 100 \mathrm{~m} \ell$, respectively, may lead to serious disease infections (DWAF, 1996b). The overall results obtained from the 3 sites along the Diep River were thus significantly $(p<0.05)$ higher than the stipulated guidelines for most of the sampling period.

Site B along the Diep River was also identified as the most contaminated site. Waste effluent from residential and industrial areas accumulates at this site and could serve as sources of contamination. Results have also shown that the high microbial counts for the MPN, FC, E. coli (SABS, 1984; 
DWAF, 1996a-c), HPC and FCM exceeded the stipulated limit for river water for most of the sampling period. It should also be noted that the results show that the FCM technique is a more reliable enumeration technique than the conventional plate count technique and it should be incorporated into the routine monitoring of environmental samples.

\section{Conclusions}

The major conclusions of the study thus include the following:

- On average, the MPN, FC and E. coli levels within the Plankenburg River notably exceeded the maximum limit of 2000 micro-organisms $/ 100 \mathrm{~m} \ell$ for river water throughout the study period (SABS, 1984; DWAF, 1996a-c).

- Contamination of the river was also confirmed with the significantly high $(\mathrm{p}<0.05)$ total FCM counts observed at all the sites along the Plankenburg River.

- The MPN, FC, E. coli, HPC and FCM results obtained from the different sites along the Plankenburg River indicate that Site B was the most contaminated site with higher counts than Sites A and C.

- Site B is situated close to the informal settlement where sanitation systems are inadequate to satisfy the needs of the inhabitants and where stormwater drainage systems and waste containers are used as a means of disposal of faecal matter. In addition, sanitation systems located in the settlement are connected to stormwater drainage pipes which enter the river system at this site.

- Even though significantly lower microbial counts were observed at Sites A and C, these sites are bordered by residential and industrial areas, respectively, which might have contributed to the increased microbial contaminants at these sites.

- Agricultural run-off from farms adjacent to the river (Plankenburg River) could also have contributed to increased contaminant levels within the river at Site A.

- The MPN, FC, E. coli, HPC and FCM counts within the Diep River also exceeded the maximum limit of 2000 micro-organisms $/ 100 \mathrm{~m} \ell$ for river water throughout the study period (SABS, 1984; DWAF, 1996a-c).

- Overall, initial increases in the bacterial counts from Site A to Site B were followed by decreases in the bacterial counts recorded at Site C. Results thus show that Site B was the most contaminated site along the Diep River. Site B is located at the Theo Marais Sportsclub, which is surrounded by major industrial and residential areas. Waste effluent from these areas accumulates at this site contributing to possible contamination.

- Site A is also bordered by industrial and residential areas, while Site $\mathrm{C}$ receives wastewater from a residential area as well as an oil-refinery. Even though no point- or nonpoint sources of contamination could be identified, the waste effluent present at the residential and industrial sites could influence water pollution at the respective sampling sites.

- Comparisons of the HPC results to the viable FCM counts, which were significantly higher $(p<0.05)$ for the Plankenburg and Diep Rivers throughout the sampling period, proved that the FCM technique is a more reliable enumeration method to accurately determine the viable bacterial counts in environmental samples.

- Overall, the significantly high microbial counts obtained for both river systems raises major human and environmental health concerns. The effectiveness of current monitor- ing and clean-up strategies by respective authorities and district municipalities should be revised to include techniques which accurately reflect the contamination levels of the river systems.

\section{Acknowledgements}

The National Research Foundation (NRF) and Cape Peninsula University of Technology (CPUT) are thanked for financial support. Koos Retief and the Blaauwberg Nature Conservation Group, as well as Ms. Shirley Clark are thanked for their assistance. Ms. Sue Kirschner (Department of Land Affairs) is thanked for her assistance.

\section{References}

AMERICAN SOCIETY FOR MICROBIOLOGY (1997) Clinical Microbiology Procedures Handbook. Vol. 1. Editor-in-chief: HD Isenberg. ASM: Washington DC. Loose-leaf format, last updated: 1997.

BARNES JM (2003) The Impact of Water Pollution from Formal and Informal Urban Developments Along the Plankenburg River on Water Quality and Health Risk. Ph.D. Dissertation, Department of Community Health, University of Stellenbosch, South Africa.

BOULOS L, PRÉVOST M, BARBEAU B, COALLIER J and DESJARDINS R (1999) LIVE/DEAD ${ }^{\circledR}$ BacLight ${ }^{\mathrm{TM}}$ : application of a new rapid staining method for direct enumeration of viable and total bacteria in drinking water. J. Microbiol. Methods. 37 77-86.

CURRENT PROTOCOLS IN CYTOMETRY (2005) Introduction. John Wiley and Sons (via Wiley InterScience). Cited online at > URL http://www3.interscience.wiley.com/cgi-bin/ mrwhome/104554804/HOME (Accessed on 2006/11/22).

DEPARTMENT OF HEALTH (2008) Cholera outbreak in Zimbabwe and South Africa. Statement by Minister of Health Barbara Hogan on the outbreak of cholera in Zimbabwe and South Africa. Cited online at > URL http://www.info.gov.za speeches/2008/08112711451003.htm (Accessed on 2009/03/05).

DEPARTMENT OF WATER AFFAIRS AND FORESTRY (1996a) South African Water Quality Guidelines for Fresh Water $\left(2^{\text {nd }}\right.$ edn.). Recreational Water Use. Environmental Services, CSIR, Pretoria, South Africa. 237.

DEPARTMENT OF WATER AFFAIRS AND FORESTRY (1996b) South African Water Quality Guidelines for Fresh Water ( $2^{\text {nd }}$ edn.). Domestic Water Use. Environmental Services, CSIR, Pretoria, South Africa. 1 77-87.

DEPARTMENT OF WATER AFFAIRS AND FORESTRY (1996c) South African Water Quality Guidelines for Fresh Water ( $2^{\text {nd }}$ edn.). Agricultural Water Use: Irrigation.: Environmental Services, CSIR, Pretoria, South Africa. 471.

DEPARTMENT OF WATER AFFAIRS AND FORESTRY (2001) South Africa. Voëlvlei Augmentation Scheme Feasibility Study. Report No. PB G100/03/1399.

DUNN OJ and CLARK VA (1987) Applied Statistics: Analysis of Variance and Regression ( $2^{\text {nd }}$ edn.). John Wiley and Sons, London, UK.

FISCHER H, SUKHODOLOV A, WILCZEK S and ENGELHARDT C (2003) Effects of flow dynamics and sediment movement on microbial activity in a Lowland River. River Res. Appl. 19 473-482.

FRIENDS OF RIETVLEI GROUP (2006-2008) ‘Blaawberg Marina Proposal'. Affiliated with Wildlife and Environmental Society (WESSA). Cited online at > URL http://www.friendsofrietvlei. co.za/BlaauwbergMarina.htm (Accessed on 2009/03/05).

GERBA CP (1996) Pathogens in the environment. In: IL Pepper, CP Gerba and ML Brusseau (eds.) Pollution Science Academic Press, New York. 279-299.

GRINDLEY JR and DUDLEY S (1988) Estuaries of the Cape, Part II: Synopses of available information on individual systems. Rep. No. 28 Rietvlei/Diep CW 24/25.

HIRAOKA Y and KIMBARA K (2002) Rapid assessment of the physiological status of the polychlorinated biphenyl degrader 
Comamonas testosteroni TK102 by flow cytometry. Appl. Environ. Microbiol. 68 (4) 2031-2035.

KELL DB, KAPRELYANTS AS, WEICHART DH, HARWOOD CR and BARER MR (1998) Viability and activity in readily culturable bacteria: a review and discussion of the practical issues. Antonie van Leeuwenhoek. 73 169-187.

LOCHNER P, BARWELL L and MORANT P (1994) Caltex Rietvlei Wetland Reserve, Management Plan Report (1 $1^{\text {st }}$ edn.) Division of Earth, Marine and Atmospheric Science and Technology, EMATEK-CSIR, Stellenbosch.

MALANDRA L, WOLFAARDT G, ZIETSMAN A and VILJOENBLOOM M (2003) Microbiology of a biological contactor for winery wastewater treatment. Water Res. 37 4125-4134.

MASSA S, GRANDI M, PODA G, CESARONI D, CANGAMELLA F and TROVATELLI LD (1988) Coliform detection from river waters: Comparison between MPN and MF techniques. Water, Air Soil Pollut 43 (1-2) 135-145.

MONIS PT, SAINT PCP, HOEFEL D, GROOBY WL and ANDREWS S (2003) Enumeration of water borne bacteria using viability assays and flow cytometry: A comparison to culture-based techniques. J. Microbiol. Methods. 55 (3) 585-597.

MULLER EE, EHLERS MM and GRABOW WOK (2001) The occurrence of E. coli O157: H7 in South African water sources intended for direct and indirect human consumption. Water Res. 35 (13) 3085-3088.

OBLINGER JL and KOBURGER JA (1975) Understanding and teaching the Most Probable Number Technique. J. Milk Food Technol. 38 (9) 540-545.

PAULSE AN, JACKSON VA and KHAN W (2007) Comparison of enumeration techniques for the investigation of bacterial pollution in the Berg River, Western Cape, South Africa. Water SA 33 (2) 165-173.

PIANETTI A, FALCIONI T, BRUSCOLINI F, SABATINI L, SISTI E and PAPA S (2005) Determination of the viability of Aeromonas hydrophilia in different types of water by flow cytometry, and comparison with classical methods. Appl. Environ. Microbiol. 12 7948-7954.

PERRI K and FALLON A (1998) Pathogen Survival and Transport in Groundwater. Groundwater Pollution Primer. CE4594: Soil and Water Pollution. Civil Engineering Department, Virginia Tech. USA.

SOUTH AFRICAN BUREAU OF STANDARDS (SABS) (1984)

South African Standard Specifications for Water for Domestic Supplies. Standard No. 241/84.

STANDARD METHODS (1992) Standard Methods for the Examination of Water and Wastewater (18 ${ }^{\text {th }}$ edn.) American Public Health Association, American Water Works Association, Water Environment Federation (Joint Publication). 9-49.

STANDARD METHODS (1995) Standard Methods for the Examination of Water and Wastewater (19 ${ }^{\text {th }}$ edn.) American Public Health Association, American Water Works Association, Water Environment Federation (Joint Publication). 9-49.

THERON J and CLOETE TE (2002) Emerging waterborne infections: Contributing factors, agents and detection tools. Crit. Rev. Microbiol. 28 (1) 1-26.

THUKELA WATER PROJECT REPORT (2004) Thukela Water Management Area. Internal Strategic Perspective. Cited online at URL $>$ www.dwaf.gov.za/Documents/Other/WMA/7/ThukelaISPNov04b.pdf (Accessed on 2006/10/15).

TIMBERG C (2006) Cholera spreading rapidly in Angola. Published in Washington Post, Washington Post Company. http://www.burundi-agnews.info/agnews18052006.htm (Accessed on 2007/02/21).

WORLD HEALTH ORGANISATION (2008) Health system problems aggravate cholera outbreak in Zimbabwe. Cited online at > URL http://www.who.int/mediacentre/news/releases/2008/pr49/en/index. html (Accessed on 2009/03/09). 